\title{
PERTUMBUHAN UDANG VANAME (Litopenaeus vannamei) DI TAMBAK INTENSIF
}

\author{
Oleh \\ Indah Purnamasari, Dewi Purnama, dan Maya Angraini Fajar Utami \\ Program Studi IImu Kelautan Fakultas Pertanian Universitas Bengkulu, \\ Bengkulu \\ Email : indahpurnamasari775@gmail.com \\ Received February 2017, Accepted March 2017
}

\begin{abstract}
ABSTRAK
Produksi yang tinggi merupakan tujuan dari budidaya udang vaname (Litopenaeus vannamei) secara intensif untuk memenuhi kebutuhan pasar dan salah satu upaya untuk meningkatkan produksi adalah dengan padat tebar tinggi. Penelitian ini bertujuan untuk untuk menganalisa pertambahan bobot dan kelangsungan hidup. Penelitian ini dilakukan dengan menggunakan metode purposif (Purposive Sampling Method). Hasil penelitian didapatkan bahwa padat tebar 170 dan 175 ekor/m2 memiliki hasil yang lebih baik diakhir pemeliharaan dilihat dari bobot rata-rata dan tingkat kelangsungan hidup yang lebih tinggi. Padat tebar 170 ekor/ $^{\mathrm{m} 2}$ menghasilkan bobot rata-rata 29,23 gram/ekor dan tingkat kelangsungan hidup 86,70. Padat tebar $175 \mathrm{ekor} / \mathrm{m}^{2}$ menghasilkan bobot rata-rata 29,18 gram/ekor dan tingkat kelangsungan hidup 82,35 .
\end{abstract}

Kata kunci : Pertumbuhan, udang Vaname, padat tebar dan tambak intensif.

\begin{abstract}
High production is the goal of intensive shrimp farming (Litopenaeus vannamei) to meet market needs. One of the efforts to increase production is by using high stocking density. This study aims to analyze the weight gain and shrimp survival. This research used Purposive Sampling Method. The results showed that stocking densities of 170 and 175 shrimps / $\mathrm{m} 2$ had better results at the end of maintenance which is known from the average weight and higher survival rate. Stocking density of 170 shrimps / $\mathrm{m} 2$ yield average weight 29,23 gram / individual and life rate 86,70 . Stocking of 175 shrimps / m2 yield average weight 29,18 gram / individual and life time 82,35.
\end{abstract}

Keywords : Growth, vaname shrimp, stocking density and intensive ponds.

\section{PENDAHULUAN}

\section{Latar Belakang}

Udang vaname (Litopenaeus vannamei) berasal dari Pantai Barat Pasifik Amerika Latin, mulai dari Peru di Selatan hingga Utara Meksiko. Udang vaname mulai masuk ke Indonesia dan dirilis secara resmi pada tahun 2001 (Nababan dkk., 2015). Udang vaname merupakan salah satu udang yang mempunyai nilai 
ekonomis dan merupakan jenis udang alternatif yang dapat dibudidayakan di Indonesia, disamping udang windu (Panaeus monodon) dan udang putih (Panaeus merguensis). Udang vaname tergolong mudah untuk dibudidayakan. Hal itu pula yang membuat para petambak udang di tanah air beberapa tahun terakhir banyak yang mengusahakannya (Amirna dkk., 2013).

Udang vaname memiliki keunggulan yang tepat untuk kegiatan budidaya udang dalam tambak antara lain: Responsif terhadap pakan/nafsu makan yang tinggi, lebih tahan terhadap serangan penyakit dan kualitas lingkungan yang buruk pertumbuhan lebih cepat, tingkat kelangsungan hidup tinggi, padat tebar cukup tinggi dan waktu pemeliharaan yang relatif singkat yakni sekitar 90 - 100 hari per siklus.

Budidaya udang vaname dengan teknologi intensif mencapai padat tebar yang tinggi berkisar 100-300 ekor/m2 (Arifin dkk., 2005 dalam Nababan, 2015). Tambak intensif adalah tambak yang dilengkapi dengan plastik mulsa yang menutupi semua bagian, pompa air, kincir air, aerator, tingkat penebaran tinggi dan pakan $100 \%$ pelet. Pakan merupakan sumber nutrisi yang terdiri dari protein, lemak, karbohidrat, vitamin dan mineral yang dibutuhkan udang untuk pertumbuhan dan perkembangan secara optimal sehingga produktivitasnya bisa ditingkatkan (Panjaitan $d k k$., 2014).

Padat tebar berperan penting dalam kegiatan budidaya untuk menentukan jumlah benur yang akan ditebar dan luas tambak yang akan digunakan. Perbedaan kepadatan yang ditebar pada setiap petak tambak berpengaruh terhadap pertumbuhan dan kelangsungan hidup udang vaname yang dihasilkan. Oleh karena itu maka perlu dilakukan penelitian tentang Pertumbuhan Udang Vaname (Litopenaeus vannamei) di Tambak Intensif".

\section{Tujuan}

Tujuan penelitian ini adalah untuk menganalisa pertumbuhan dan kelangsungan hidup udang vaname di tambak intensif.

\section{MATERI DAN METODE}

\section{Tempat dan Waktu Penelitian}

Penelitian dilaksanakan pada bulan Maret-Juli 2016 di tambak udang Intensif Kilau Samudra Desa Palapan Kecamatan Pondok Kelapa Kabupaten Bengkulu Tengah.

\section{Alat dan Bahan}

Alat dan bahan yang digunakan selama penelitian dapat di lihat pada Tabel 1. Tabel 1. Alat dan bahan yang digunakan dalam penelitian

\begin{tabular}{lll}
\hline No & \multicolumn{1}{c}{ Alat/Bahan } & \multicolumn{1}{c}{ Kegunaan } \\
\hline 1 & Benur berat $0.02(\mathrm{gr})$ & Sampel penelitian \\
2 & Pakan udang & Makanan udang selama pemeliharaan \\
3 & Saponin & Obat pemberantas hama \\
4 & Kincir air & Menspulai oksigen \\
5 & Plastik mulsa & Penutup pinggir tambak \\
6 & Pupuk pertanian $\left(\mathrm{CaCO}_{3}\right)$ & Menaikan pH tambak \\
7 & Anco & Mengecek udang dan sisa pakan \\
\hline
\end{tabular}




\begin{tabular}{|c|c|c|}
\hline 8 & $\mathrm{pH}$ Meter & Mengukur $\mathrm{Ph}$ \\
\hline 9 & Termometer & Mengukur suhu \\
\hline 10 & Refaktrometer & Mengukur salinitas \\
\hline 11 & DO meter & Mengukur oksigen terlarut \\
\hline 12 & Jala $4 m^{2}$ & $\begin{array}{l}\text { Mengambil udang saat sampling dan } \\
\text { panen }\end{array}$ \\
\hline 13 & Timbangan & $\begin{array}{l}\text { Menimbang saat panen dan } \\
\text { sampling }\end{array}$ \\
\hline
\end{tabular}

\section{Penentuan Lokasi Penelitian}

Penentuan titik sampling dalam penelitian ini dilakukan dengan menggunakan metode purposif (Purposive Sampling Method). Metode ini merupakan metode pengambilan sampel yang dilakukan didasarkan atas tujuan tertentu. Teknik ini biasanya dilakukan karena beberapa pertimbangan, misalnya alasan keterbatasan waktu, tenaga dan dana, namun harus tetap memperhatikan syarat-syarat yang harus dipenuhi misalnya subyek yang diambil sebagai sampel benar-benar merupakan subjek yang paling banyak mengandung ciri-ciri yang terdapat pada populasi (key subjectis) (Arikunto, 2010).

\section{Penentuan Padat Tebar}

Pada Peneliian ini menggunakan 6 petak tambak dengan padat tebar yang berbeda. Petak B1 luas $1200 \mathrm{~m}^{2}$ dengan padat tebar $170 \mathrm{ekor} / \mathrm{m}^{2}$, Petak B2 luas $1300 \mathrm{~m}^{2}$ dengan padat tebar $175 \mathrm{ekor} / \mathrm{m}^{2}$, Petak B3 luas $1400 \mathrm{~m}^{2}$ dengan padat tebar $180 \mathrm{ekor} / \mathrm{m}^{2}$, Petak B4 luas $1500 \mathrm{~m}^{2}$ dengan padat tebar $185 \mathrm{ekor} / \mathrm{m}^{2}$, Petak B5 luas $1600 \mathrm{~m}^{2}$ dengan padat tebar $190 \mathrm{ekor} / \mathrm{m}^{2}$ dan Petak B6 luas $1700 \mathrm{~m}^{2}$ dengan padat tebar $195 \mathrm{ekor} / \mathrm{m}^{2}$.

\section{Persiapan Tambak}

Kegiatan persiapan tambak terdiri dari pengeringan, pengapuran, pengisian air dan penumbuhan plankton hingga tambak siap untuk di tebar.

\section{Penebaran Benur dan pengambilan sampel Udang Vaname}

Penebaran benur dilakukan pada pagi hari, yang diawali dengan aklimatisasi benur terlebih dahulu, terutama pada suhu dan salinitas. Setelah suhu dan salinitas air pada kantong plastik benur sama atau tidak berbeda jauh dengan air tambak, maka benih udang dapat ditebar secara perlahan-lahan ke tambak. Kegiatan sampling pertama dilakukan pada saat udang mencapai umur 45 hari pemeliharaan di tambak. Sedangkan sampling berikutnya dilakukan setiap 7 hari sekali dari sampling sebelumnya.

\section{Pemanenan Udang Vaname}

Pemanenan dilakukan dua kali yaitu panen parsial dan panen total. Panen parsial adalah panen udang sebagian untuk mengurangi kepadatan udang ditambak. Panen parsial dilakukan ketika udang berumur 101-104 hari dengan bobot rata-rata berkisar antara 21,85-22,70 gram dan ukuran udang berkisar antara 44-45 ekor/kg. Panen total adalah panen udang secara keseluruan (kering). Panen total dilakukan ketika udang berumur 125-126 hari 
dengan bobot rata-rata berkisar antara 28,07-29,23 gram dan ukuran udang berkisar antara 34-35 ekor/kg.

\section{Pertambahan bobot udang}

Untuk mengetahui pertambahan bobot rata-rata udang hasil sampling setiap minggunya dihitung menggunakan rumus sebagai berikut :

$$
W=\frac{\mathbf{B}}{\mathbf{N}}
$$

Ket :

$\mathrm{W}=$ Bobot rata-rata udang (gr)

$\mathrm{B} \quad=$ Bobot seluruh udang sampling (gr)

$\mathrm{N} \quad=$ Jumlah udang (ekor)

\section{Kelangsungan Hidup (\%)}

Kelangsungan hidup untuk mengetahui kelulushidupan udang diakhir pemeliharaan. Dihitung menggunakan rumus Haliman dan Adiwijaya (2005) dalam Fuady dkk. (2013):

$$
\mathrm{SR}=\frac{N_{\mathrm{t}}}{\mathrm{N}_{\mathrm{o}}} \times 100 \%
$$

Ket :

$\mathrm{SR} \quad=$ Tingkat kelangsungan hidup (\%)

$\mathrm{Nt} \quad=$ Jumlah udang hidup pada akhir pemeliharaan (ekor)

No = Jumlah udang pada awal pemeliharaan (ekor)

\section{Kualitas Air}

Pengukuran kualitas air tambak (suhu, salinitas $\mathrm{pH}$ (derajat keasaman oksigen terlarut (dissolved oksigen/DO).

\section{HASIL DAN PEMBAHASAN}

\section{Pertambahan bobot udang}

Pemeliharaan udang vaname pada penelitian ini berlangsung selama 126 hari dan dilakukan pengukuran pertambahan bobot yang dapat dilihat pada Gambar 1. Grafik bobot rata-rata udang vaname menunjukan bahwa bobot rata-rata udang yang dihasilkan pada setiap petak tambak dari awal sampai akhir pemeliharaan terus mengalami peningkatan setiap minggunya. 


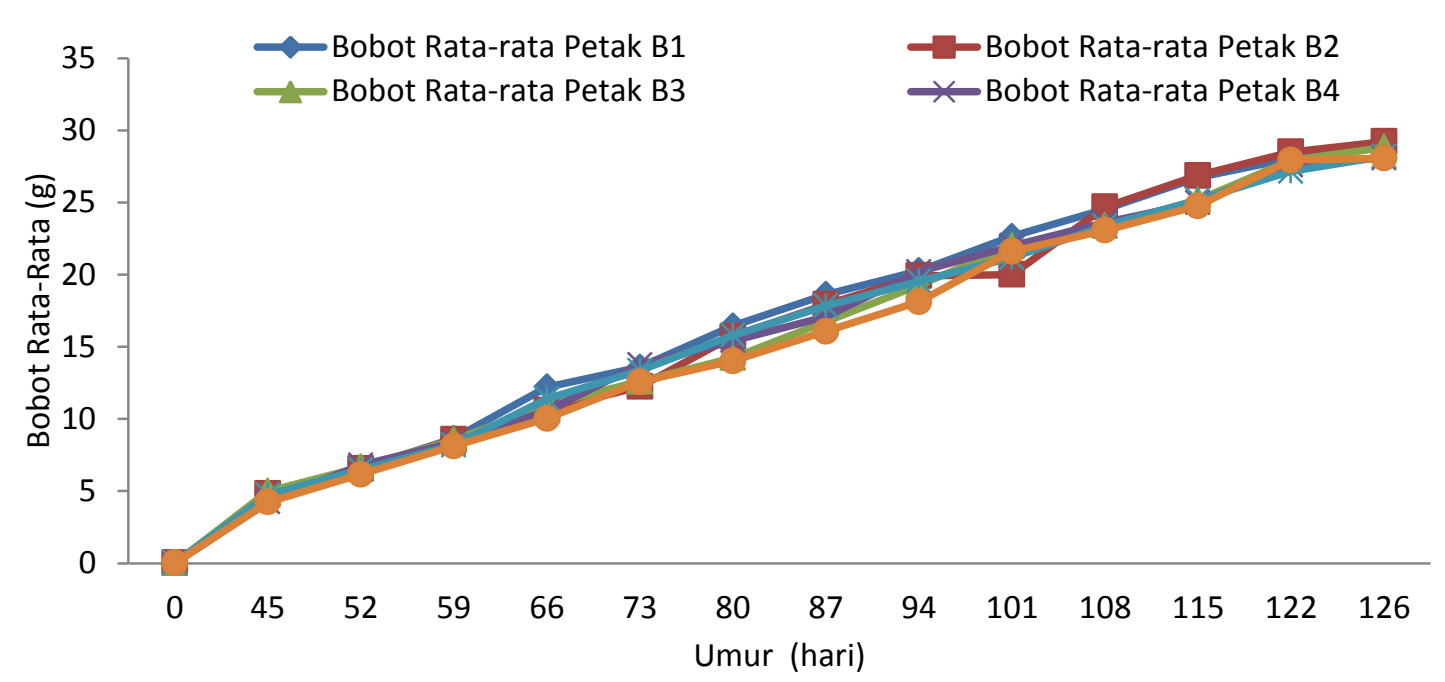

Gambar 1. Pertambahan bobot udang vanane selama pemeliharaan

Petak tambak B1 dan B2 dengan padat penebaran awal 170 dan 175 ekor $/ \mathrm{m}^{2}$ memiliki bobot rata-rata lebih tinggi diakhir pemeliharaan masingmasing yaitu 29,23 dan 29,18 gram/ekor. Bobot rata-rata udang yang dihasilkan pada petak B1 dan B2 terus mengalami peningkatan seiring dengan bertambahnya masa pemeliharaan. Hal ini diduga karena jumlah populasi udang yang lebih sedikit, sehingga pertambahan bobot rata-rata yang dihasilkan diakhir pemeliharaan dapat lebih optimal, yang dilihat dari hasil sampling setiap minggunya dengan tingkat pertumbuhan 1-2,5 gram/minggu. Hal ini sesuai dengan pernyataan Supono (2006) yang menyatakan bahwa udang vaname dapat tumbuh baik dengan tingkat pertumbuhan 1-1,5 gr/minggu. Sedangkan petak tambak B4 dan B6 dengan padat penebaran awal 185 dan 195 ekor $/ \mathrm{m}^{2}$ memiliki bobot rata-rata lebih rendah diakhir pemeliharaan masing-masing yaitu 28,09 dan 28,07 gram/ekor. Rendahnya bobot rata-rata yang dihasilkan pada petak B4 dan B6 diduga karena jumlah populasi udang yang lebih banyak, sehingga ruang gerak udang dalam mendapatkan makanan, tempat hidup dan oksigen terbatas yang menyebabkan pertambahan bobot rata-rata udang yang dihasilkan diakhir pemeliharaan tidak dapat maksimal.

\section{Kelangsungan Hidup (\%)}

Tingkat kelangsungan hidup udang vaname pada setiap petak tambak bervariasi, seperti dapat dilihat pada Gambar 2. Petak tambak B1 dan B2 memiliki tingkat kelangsungan hidup lebih tinggi. Tingginya kelangsungan hidup pada petak B1 dan B2 diduga karena kepadatan rendah sehingga pakan yang diberikan dapat dimanfaatkan dengan baik oleh udang untuk pertumbuhan yang lebih optimal, terlihat dari pertambahan bobot rata-rata diakhir dan laju pertumbuhan udang selama pemeliharaan yang lebih tinggi serta kualitas air tambak cukup baik yang masih bisa ditoleransi oleh udang untuk pertumbuhan dan kelangsungan hidupnya. Hal ini sesuai dengan pernyataan Yustianti $d k k$. (2013) yang menyatakan bahwa faktor yang paling mempengaruhi 
kelangsungan hidup udang yaitu pengelolaan dalam pemberian pakan dan pengelolaan kualitas air yang baik pada media pemeliharaan.

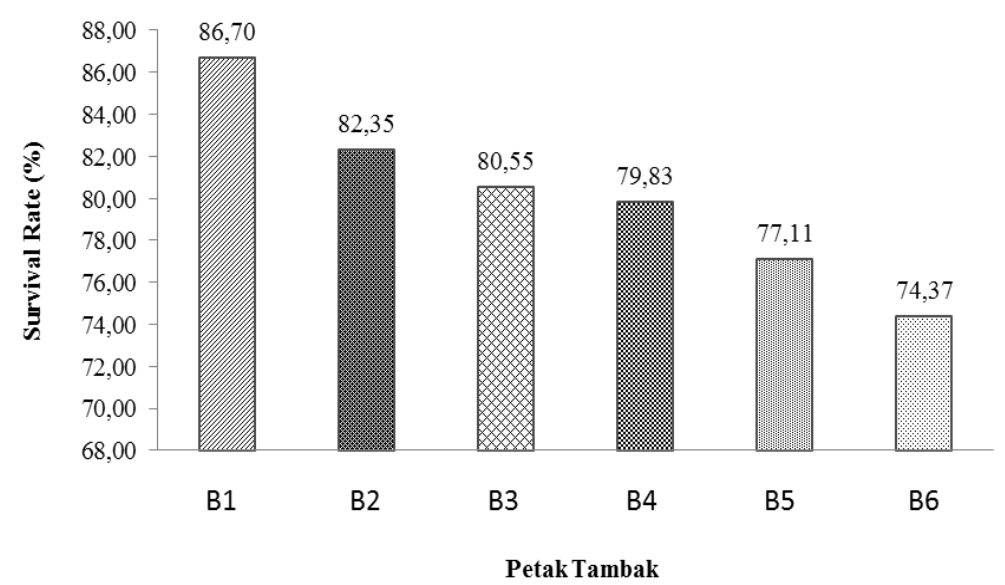

Gambar 2. Kelangsungan hidup udang vaname

Petak tambak B5 dan B6 memiliki tingkat kelangsungan hidup lebih rendah. Rendahnya tingkat kelangsungan hidup pada petak B5 dan B6 diduga karena kepadatan tinggi dan adanya sifat kanibalisme. Pada kepadatan tinggi sering terjadi kompetisi udang dalam memperebutkan makanan yang mengakibatkan udang suka memangsa sesama jenis karena pakan yang diberikan kurang sehingga berdampak terhadap pertumbuhan yang tidak merata dan tingkat kematian yang tinggi. Hal ini sesuai dengan pernyataan Muzaki (2004) yang menyatakan bahwa menurunnya tingkat kelangsungan hidup udang disebabkan karena padat penebaran tinggi akan meningkatkan kompetisi udang dalam mendapatkan makanan, ruang gerak,tempat hidup dan oksigen. Serta udang memiliki sifat kanibalisme yaitu suka memangsa sesama jenis (Hidayat $d k k$., 2013). Sifat tersebut dapat muncul bila udang mengalami stress atau pakan yang diberikan kurang.

\section{Kualitas Air}

Nilai salinitas tambak dapat dilihat pada gambar3 dan terlihat bahwa terdapat variasi naik dan turunnya salinitas pada setiap petak tambak. Kenaikan salinitas ini terjadi karena pada saat pengukuran salinitas cuaca panas, suhu udara naik dan terjadi penguapan air tambak sehingga kandungan air garam meningkat yang menyebabkan salinitas tinggi tetapi tidak sampai menyebabkan kematian udang dan tidak mempengaruhi produksi. Langkah yang dapat dilakukan untuk mengatasi tingginya salinitas air tambak adalah dengan membuang sebagian air didalam tambak dan menggantinya dengan air tawar sehingga salinitas dapat optimal. 


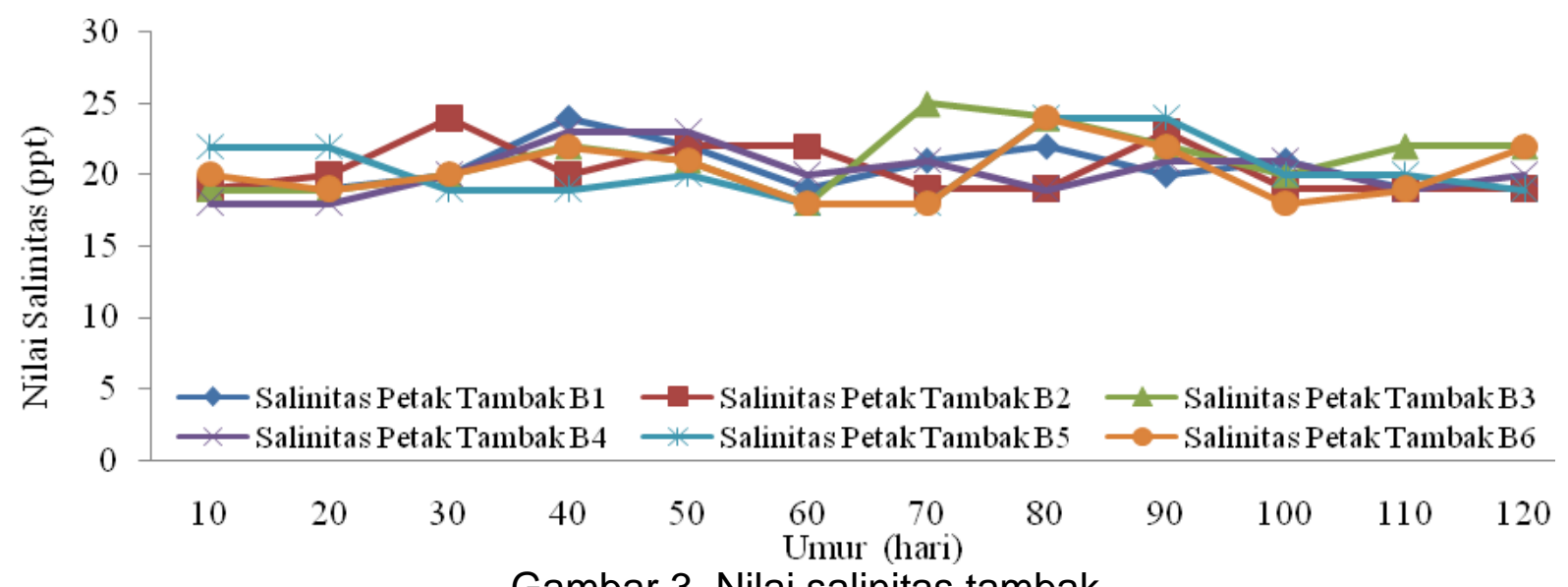

Gambar 3. Nilai salinitas tambak

Penurunan salinitas juga terlihat pada setiap petak tambak. Penurunan salinitas ini dikarenakan pada saat sampling sering terjadi hujan yang menyebabkan salinitas turun sehingga konsentrasi kadar garam berubah karena adanya kandungan air tawar, akan tetapi tidak mempengaruhi produksi udang. Langkah yang dapat dilakukan untuk mengatasi rendahnya salinitas adalah dengan menambah input air laut dari tandon yang dialirkan melalui pipa paralon menggunakan pompa air. Kenaikan dan penurunan salinitas yang terjadi masih berada dalam kisaran optimal dan masih mendukung pertumbuhan dan kehidupan udang vaname. Hal ini sesuai dengan pernyataan Nababan dkk. (2015) menyatakan bahwa salinitas yang baik untuk pertumbuhan berkisar antara 10-30 ppt.

Gambar 4 menujukkkan variasi perubahan $\mathrm{pH}$ selama pemeliharaan udang vaname dan terlihat bahwa terdapat variasi naik dan turunnya $\mathrm{pH}$ pada setiap petak tambak. Kenaikan $\mathrm{pH}$ ini terjadi karena disebabkan oleh limbah dari sisa pakan yang telah mengedap dan mengalami pembusukan yang mengakibatkan $\mathrm{pH}$ air tambak naik.

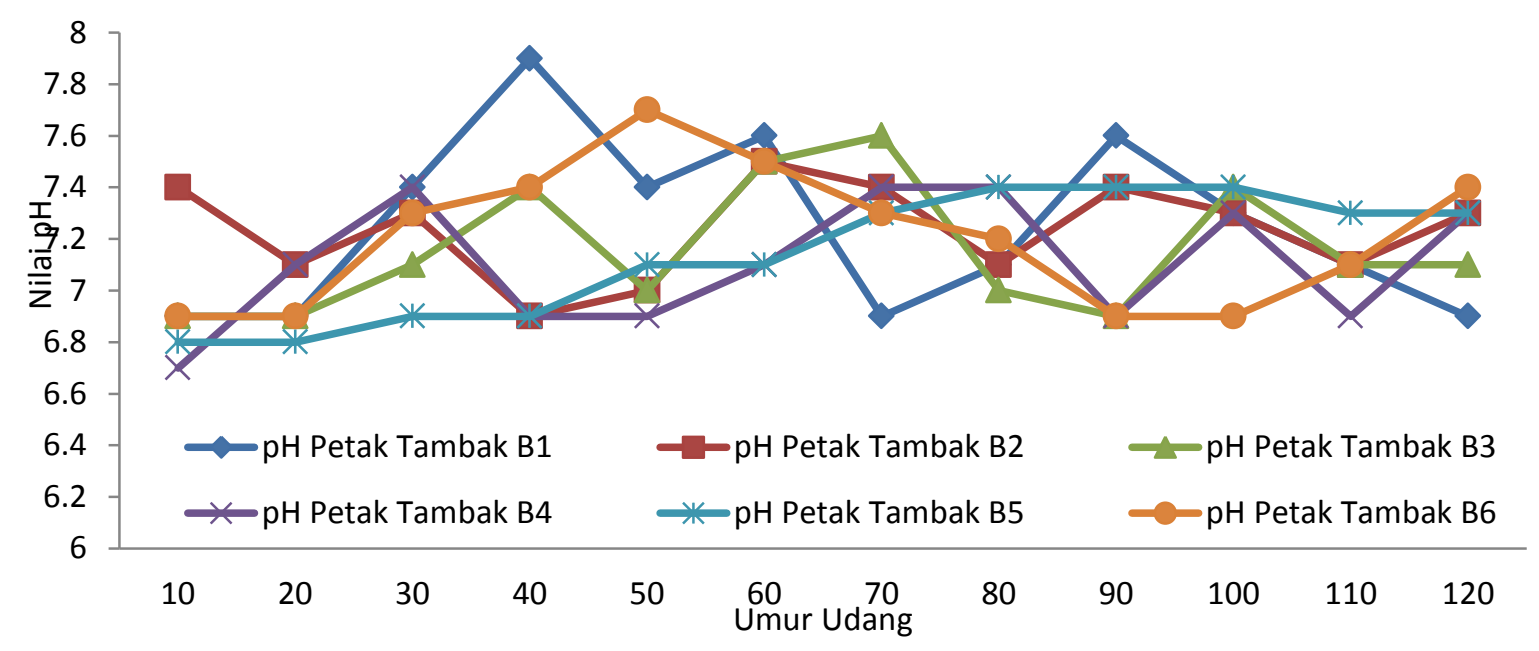

Gambar 4. Nilai pH selama pemeliharaan 
Penurunan $\mathrm{pH}$ juga terlihat pada setiap petak tambak. Penurunan $\mathrm{pH}$ dikarenakan adanya air masuk dari tandon dan masukan air hujan keseluruh petak tambak, akan tetapi penurunanya tidak terjadi secara spontan dan tidak mempengaruhi produksi udang. Kenaikan dan penurunan $\mathrm{pH}$ yang terjadi masih dalam kisaran optimal dan cukup ideal untuk pertumbuhan dan kelangsungan hidup udang vaname. Hal ini sesuai dengan pernyataan Amri dan Iskandar (2008) dalam Amirna dkk. (2013) yang menyatakan bahwa nilai $\mathrm{pH}$ yang normal untuk pertumbuhan udang vaname adalah berkisar antara 7,58,5. Perubahan $\mathrm{pH}$ sehari-hari dapat mengakibatkan stres pada hewan air. Sehingga pengapuran digunakan untuk meningkatkan alkalinitas total dan diperlukan untuk kestabilan penyangga perairan dan mengurangi fluktuasi pada $\mathrm{pH}$ harian.

Nilai oksigen terlarut (Disolved oxygen/DO) selama pemeliharaan ditunjukkan pada gambar 5 dan variasi naik dan turunnya oksigen terlarut pada setiap petak tambak. Kenaikan oksigen terlarut ini terjadi disebabkan karena pengukuran dilakukan pada siang hari, tambak memiliki oksigen terlarut cenderung tinggi karena adanya proses fotosentesis plankton yang menghasilkan oksigen yang menyebabkan oksigen terlarut meningkat. Keadaan sebaliknya pada malam hari plankton tidak melakukan fotosintesis bahkan membutuhkan oksigen sehingga terjadi kompetitor bagi udang dalam mengambil oksigen. Upaya yang dilakukan untuk meningkatkan produksi oksigen adalah dengan pemakaian kincir air.

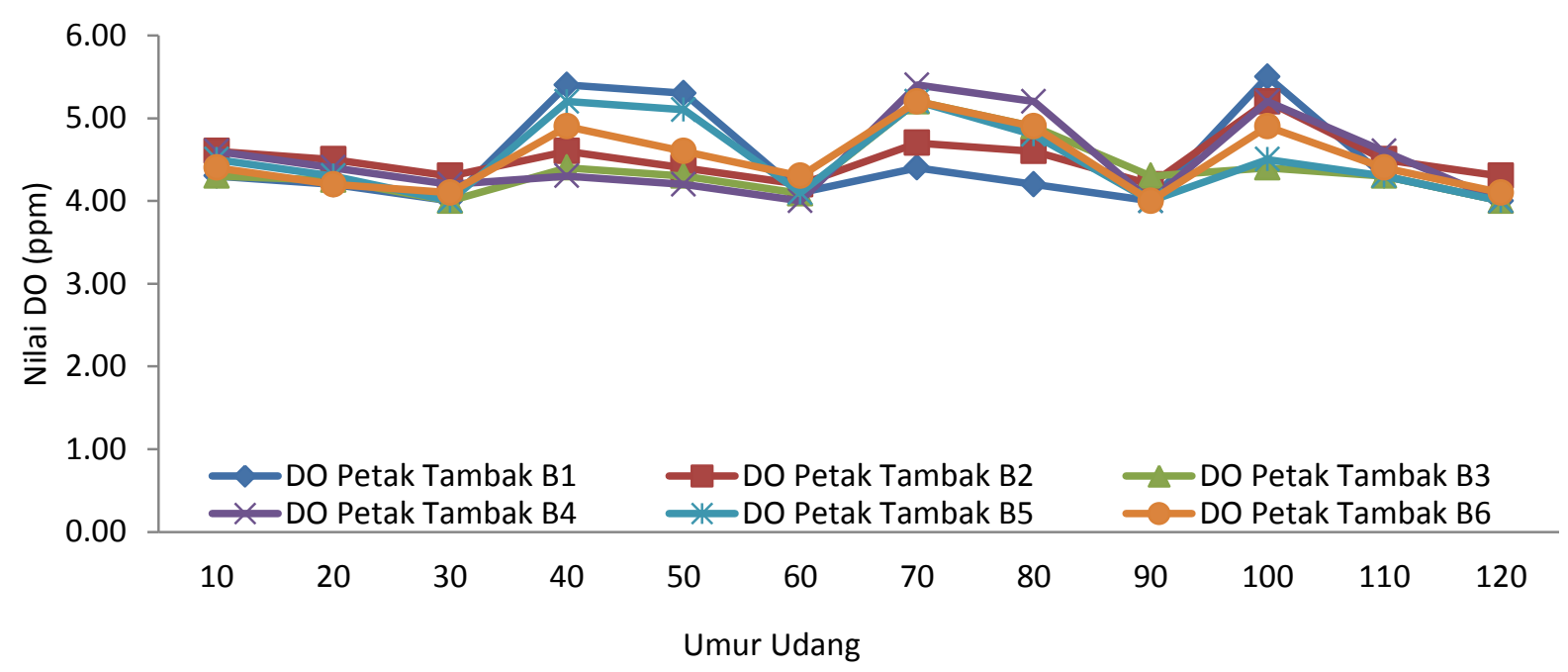

Gambar 5. Nilai oksigen terlarut selama pemeliharaan

Penurunan oksigen terlarut juga terlihat pada setiap petak tambak. Penurunan oksigen terlarut ini dikarenakan pengukuran dilakukan pada sore hari, oksigen terlarut lebih rendah dibandingkan siang hari atau pagi hari ini dikarenakan fitoplankton tidak berfotosintesis bahkan sebaliknya mengkonsumsi oksigen akan tetapi tidak mempengaruhi produksi udang. Kenaikan dan penurunan oksigen terlarut yang terjadi masih dalam kisaran 
optimal dan cukup ideal bagi pertumbuhan dan kelangsungan hidup udang vaname. Hal ini sesuai dengan pernyataan Amri dan Iskandar (2008) dalam Amirna dkk. (2013) menyatakan bahwa kandungan oksigen terlarut yang baik untuk kehidupaan udang vaname adalah 4-8 mg/l.

Variasi naik dan turunnya suhu pada setiap petak tambak. Kenaikan suhu ini terjadi disebabkan karena banyaknya intensitas cahaya yang jatuh pada permukaan air dan tambak yang digunakan lebih kecil dan nilai suhu dapat dilihat pada gambar 6 . Karena semakin kecil tambak yang digunakan maka volume air juga lebih sedikit, sehingga cahaya matahari yang jatuh pada permukaan air akan lebih cepat memuai dan suhu akan lebih cepait naik. Hal ini sesuai dengan pernyataan (Feriningtyas, 2005 dalam Simbolon, 2014) yang menyatakan bahwa dalam keadaan cerah atau panas suhu air dipermukaan tambak dapat mencapai 33-34 ${ }^{\circ} \mathrm{C}$. Suhu tersebut dapat meningkat lebih tinggi sampai $40^{\circ} \mathrm{C}$ apabila keadaan air sangat dangkal atau wadah yang digunakan lebih kecil. Namun sebagian intensitas cahaya tersebut juga dipantulkan kembali ke atmosfer dan yang tersisa akan tersimpan pada badan air dalam bentuk energi.

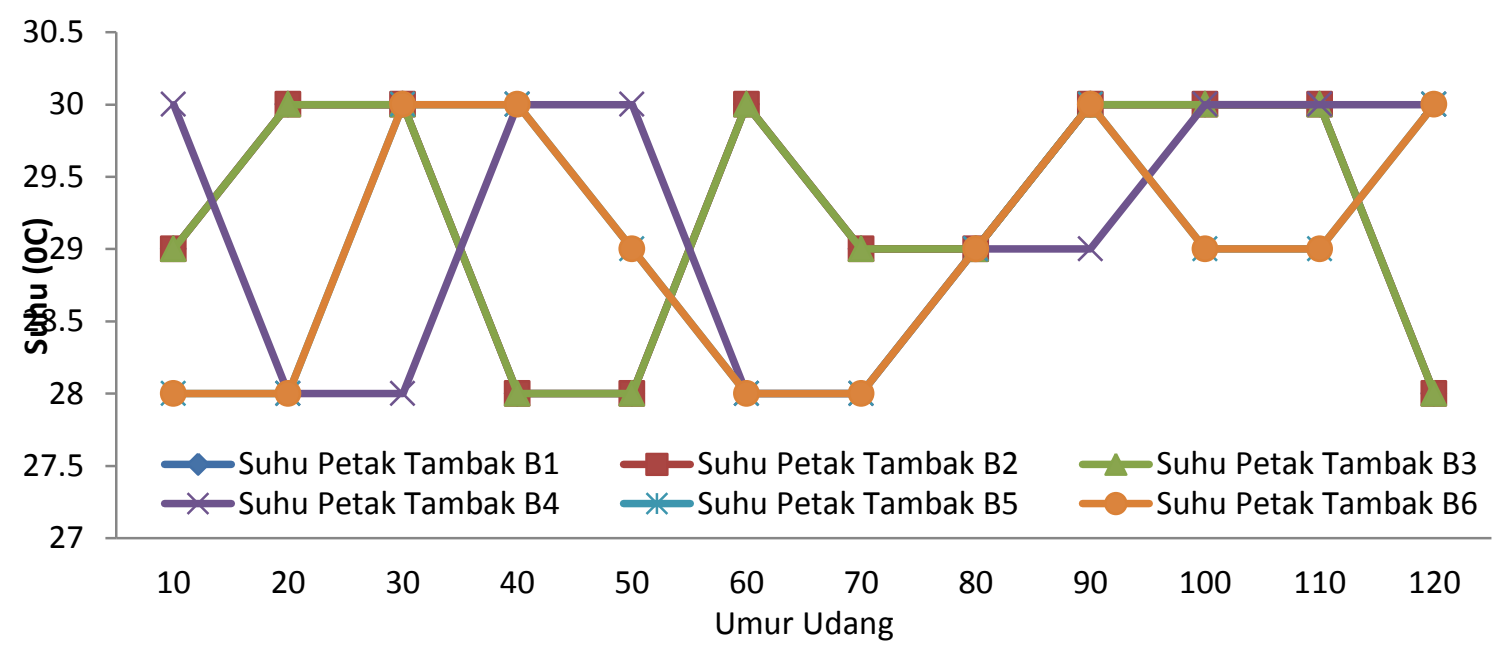

Gambar 6. Nilai suhu selama pemeliharaan

Penurunan suhu juga terlihat pada setiap petak tambak. Penurunan suhu terjadi dikarenakan saat pengambilan sampling sering terjadi hujan yang menyebabkan turunya suhu air tambak, akan tetapi kemampuan udang cukup baik untuk beradaptasi dikarenakan umur udang cukup dewasa dan sifat dari udang itu sendiri yang lebih tahan terhadap perubahan lingkungan. Kenaikan dan penurunan suhu yang terjadi masih dalam kisaran optimal dan cukup baik bagi pertumbuhan dan kelangsungan hidup udang vaname. Hal ini sesuai dengan pernyataan Baliao dan Siri (2002) dalam Amirna dkk. (2013) yang menyatakan bahwa kondisi suhu yang ideal bagi kehidupan udang vaname adalah air yang mempunyai suhu berkisar $28-31{ }^{\circ} \mathrm{C}$. 


\section{KESIMPULAN}

Berdasarkan hasil penelitian disimpulkan bahwa padat tebar 170 dan $175 \mathrm{ekor} / \mathrm{m}^{2}$ menghasilkan bobot rata-rata dan tingkat kelangsungan hidup yang lebih baik.

\section{DAFTAR PUSTAKA}

Amirna, O., R., Iba dan A. Rahman. 2013. Pemberian silase ikan gabus pada pakan buatan bagi pertumbuhan dan kelangsungan hidup udang vaname (Litopenaeus vannamei) pada stadia post larva. Jurnal Minat Indonesia Vol. 01 No. 01 hal. (93-103) ISSN : 2303-3959. Universitas Haluoleo Kampus Hijau Bumi Tridarma. Kendari.

Arikunto, 2010. Prosedur Penelitian : Suatu Pendekatan Praktek (Edisi revisi). PT. Pemuda Cipta. Jakarta. $413 \mathrm{hlm}$.

Hidayat, D., Sasanti, A. D, dan Yulisman. 2013. Kelangsungan hidup, pertumbuhan dan efisiensi pakan ikan gabus (Channa striata) yang diberi pakan berbahan baku tepung keong mas (Pomacea sp). Jurnal Akuakultur Rawa Indonesia, 1(2) :161-172 (2013) ISSN : 2303-2960. Universitas Sriwijaya, Indralaya, Ogan Ilir 30662Panjaitan, S.A., W. Hadie, dan S. Harijati. 2014. Pemeliharaan larva udang vaname (Litopenaeus vannamei) boone 1931) dengan pemberian jenis fitoplankton yang berbeda. Jurnal Manajemen Perikanan dan Kelautan Volume (1) No. 1. Artikel 2. Universitas Terbuka. Jakarta.

Nababan, E., Putra I., dan Rusliadi. 2015. Pemeliharaan udang vaname (Litopenaeus vannamei) dengan persentase pemberian pakan yang berbeda. Jurnal IImiah Perikanan dan Kelautan Vol. 3 No. 2. Universitas Riau. Kampus Bina Widya KM. 12,5 Simpang Baru Pekanbaru 282943.

Supono. 2006. Produktivitas udang putih pada tambak intensif di tulang bawang lampung. Jurnal Saintek Perikanan Vol. 2 No. 1 Hal : 48-53. Universitas Lampung. Lampung.

Simbolon, A. 2014. Studi kualitas pada budidaya udang vaname (Litopenaeus vannamei) ditambak Pt. Cendana Pioritas Lestari Pondok Kelapa melaui analisis indeks storet. Skripsi. Program Studi IImu Kelautan. Fakultas Pertanian. Universitas Bengkulu.

Yustianti, M. N. Ibrahim, dan Ruslaini. 2013. Pertumbuhan dan sintasan larva udang vaname (Litopenaeus vannamei) melalui substitusi tepung ikan dengan tepung usus ayam. Jurnal Mina Laut Indonesia Vol. 01 No. 01 (93 - 103) ISSN : 2303-3959. Universitas Haluoleo Kampus Hijau Bumi Tridharma Kendari. 